\title{
A Theory Of Bust-Up Corporate Takeovers
}

Thomas G. E. Williams, (E-mail: tgewilliams@uncfsu.edu) Fayetteville State University

Christopher J. Marquette, (E-mail: cjm29@ pitt.edu), University of Pittsburgh, Greensburg

\begin{abstract}
Quite often, the market value of a firm in parts exceeds its value as a single entity. The maximum value can be attained in such instances, by splitting the firm up. We observe several instances where a firm's management breaks up the firm to achieve maximum value. In other cases, firms require a change in management to initiate divestiture. Lastly, takeover by outsiders is sometimes required to split the firm up and sell it in parts to achieve full value. This study provides an economic analysis of the payoffs to all parties involved in a corporate breakup. Models of the costs and benefits to shareholders and management teams are developed for each of the three situations listed above to explain why the different circumstances occur in different cases.
\end{abstract}

\section{INTRODUCTION}

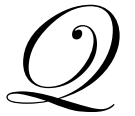

uite often, the market value of a firm in parts exceeds its value as a single entity. In such instances, shareholders can realize the maximum value of their investment if the company's managers break the firm up. Yet we observe several instances where firms are taken over by outsiders and subsequently split up and sold in parts by the new owners. Following some acquisitions, acquirers are required to sell parts of these firms because of anti-trust issues. The practice is common in regulated industries such as banking, energy, and utilities, where acquirers may be required to divest portions of the acquired firm or withdraw from certain segments of the market by getting rid of some assets. Among the several examples are the Federal Trade Commission approval of the acquisition of Gulf Oil Corp by Chevron in 1984, the Federal Reserve approval of First Union acquisition of Corestates Financial Corp in 1998, the Federal Communications Commission approval of GTE Corp merger with Bell Atlantic in 1999, and the Federal Energy Regulatory Commission approval American Electric Power Co. acquisition of Central \& South West in 2000. In each case the new entity had to dispose of assets as a condition of the approval granted by the regulatory agency. However, in many cases, the only apparent reason for the takeover and subsequent split-up is for value extraction. The cases of outsiders acquiring firms and splitting them up for value extraction raises the question of why the incumbent management team did not divest the firm themselves with the original shareholders receiving the extracted value. To answer this question we examine the costs associated with divestiture.

We review the cost structures of three different situations: an incumbent management team splitting up the firm, an incumbent management team refusing to split the firm up is replaced by a management team that will divest and divestiture by outsiders after a takeover. Developing the theoretical basis for the costs in these different cases provides the basis for a study of the market and governance frictions that inhibit divestiture by incumbent management when the value of a firm is greater in parts than it is as a single entity.

\section{THEORY AND MODEL}

The theoretical basis for this analysis focuses on the value-maximizing objective of the firms' managers. Managers are expected to pursue the course of action that results in the maximum value of the firm. Consequently, when a firm is of greater value in parts than it is as a single entity, value-maximizing managers should split the firm up. There are, in fact, many instances when incumbent managers undertake divestitures voluntarily. However, we also observe situations where a firm is taken over by outsiders only to be split into parts and sold. The third possibility requires that the management team be removed and replaced by a new team that splits the firm up. 
Consider a firm with the current market value as a single entity denoted by $V_{m}$ and its true value in parts denoted by $V_{t}$, with $V_{t}>V_{m}>0$. The firm's managers, as insiders, have access to private and proprietary information that is not available to outsiders. Therefore, incumbent managers have a better estimate of the true value of the firm than do outsiders. Outsiders must incur costs to secure the information required to estimate the value of the firm. Not only do outsiders incur costs not applicable to incumbent managers, but also the information they gather is likely to be less accurate than the information possessed by incumbent managers. The costs incurred by outsiders for gathering and processing information about the firm is denoted by $c$. All that matters for the purpose of this paper, however, is that it is more costly for outsiders to determine the value of the firm. Outsiders will take over a firm, split it up and sell the parts only when it is profitable for them to do so, that is, their profit from the transaction $\left(\Pi_{O}\right)$ is greater than zero. Therefore, the true value of the firm (in parts) must exceed the market value of the firm as a single entity by some minimum amount before it becomes profitable for outsiders to invest the resources necessary to determine the value of the firm, and then initiate a takeover.

\section{Incumbent Manager Divestiture}

To arrive at an estimate of the true value of a firm $V_{t}$, let us assume that incumbent managers incur no costs beyond those, which are included as part of the firm's operating expenses. Therefore, these expenses are already accounted for in the observed market value of the firm. Consequently, value-maximizing managers carry out a divestiture when the true value of the firm in parts exceeds the market value of the firm as a single entity. Incumbent managers may choose to do carve out, a spin-off or a sell-off. In a comparison of spin-offs and sell-offs, Steiner (1997) finds that incumbent managers tend to do a sell-off when the parent is unprofitable, has a high level of long-term debt, and managers own less of the equity. The amount by which the value of the firm in parts $\left(\mathrm{V}_{\mathrm{t}}\right)$ exceeds the value of the firm as a single entity is defined as the divestiture premium, denoted by $\mathrm{W}_{\mathrm{I}}$. The divestiture premium is represented as $\mathrm{W}_{\mathrm{I}}=\mathrm{V}_{\mathrm{t}}-\mathrm{V}_{\mathrm{m}}>0$. In other words, we should expect incumbent managers to undertake a divestiture when the divestiture premium earned by current shareholders is positive. On the other hand, it is only economical for outsiders to take over a firm and split it up when the difference between their estimated value of the firm in parts and the value of the firm as a single entity is substantially greater than zero. The difference must be sufficiently large to cover information costs and provide a return to the outsiders that is commensurate with the risk of takeover. We define as a split-up premium, denoted by $\mathrm{W}_{\mathrm{O}}$, the amount by which the value of the firm in parts as estimated by outsiders exceeds the amount paid by outsiders who take the firm over and then sell it off in parts. It is presumed that outsiders always pay a takeover premium, denoted by $p$, to existing shareholders to gain control of the firm. Therefore, the split-up premium must be sufficiently large to cover the information gathering and processing costs, and provide a suitable return for the outsiders who take the firm over. The takeover premium paid to existing shareholders must be sufficiently large to entice them to tender the minimum number of shares required to facilitate the takeover. The takeover premium must be greater than some minimum value, whereby the number of shares tendered will be large enough to facilitate a successful takeover. The necessary condition for a successful outsider-initiated takeover is that the split-up premium exceeds the information costs, that is, $\mathrm{W}_{\mathrm{O}}$ must be greater than c. Here, we characterize as successful, a takeover that is profitable for the outsiders who take over the firm and split it up.

On the contrary some takeovers may turn out to be unprofitable for the outsiders. This occurs when outsiders make an incorrect estimate of the value of the firm in parts $\left(\mathrm{V}_{\mathrm{t}}\right)$, and therefore, pay too much for the firm, akin to the hubris hypothesis presented by Roll (1986) and Shleifer \& Vishny (1989). These bad acquisitions also appear to result in subsequent divestitures as reported by Mitchell \& Lehn (1990), who found that acquisitions that were subsequently divested were the ones unfavorably received by investors. Outsiders overpay when the split-up premium is not sufficiently large to cover the costs of gathering and processing information. In addition to the cases where outsiders incorrectly estimate $V_{t}$, overpayment may also result from outsiders paying an excessive takeover premium to gain control of the firm. For these 'hubristic' takeovers, the split-up premium turns out to be less than 
$\underline{1}$ the information costs, $\mathrm{W}_{\mathrm{O}}<\mathrm{c}$. Even when $\mathrm{W}_{\mathrm{O}}>\mathrm{c}$, the net profits $\Pi_{\mathrm{O}}$ must still reach some minimum level before these takeovers become viable.

However, we focus on those instances where outsiders do not overpay. Only in these cases, with $\mathrm{W}_{\mathrm{O}}>\mathrm{c}$, is it possible for outsiders to take over the firm and profitably split it up into parts. These divestitures are considered to be successful. However other studies (Bergh; 1997; Porter, 1987) characterize acquisitions that are subsequently divested as failures. Consistent with our conjecture, Kaplan \& Weisbach (1992) analysis of 271 acquisitions between 1971 and 1992 suggest that many divested acquisitions were not failures. Focusing on these successful acquisitions, let us assume outsiders make an accurate estimate of the value of the firm in parts or at least their estimate is sufficiently accurate so that $\mathrm{W}_{\mathrm{O}}>\mathrm{c}$. In such instances the outsiders receive the value of the firm in parts and pays out the market value plus the takeover premium, so that:

$\mathrm{W}_{\mathrm{O}}=\mathrm{V}_{\mathrm{t}}-\left(\mathrm{V}_{\mathrm{m}}+\mathrm{p}\right)=\left(\mathrm{V}_{\mathrm{t}}-\mathrm{V}_{\mathrm{m}}\right)-\mathrm{p}=\mathrm{W}_{\mathrm{I}}-\mathrm{p}>\mathrm{c}$

With c being a positive number, equation (1) implies that $\mathrm{W}_{\mathrm{I}}>\mathrm{p}$. Therefore, in all instances where outsiders profitably take over and split up the firm, current shareholders would be better off if incumbent managers undertake a divestiture, since their net gain $\mathrm{W}_{\mathrm{I}}$ is greater than the takeover premium they receive from the outsiders. This result implies that existing shareholders lose in all instances where outsiders take over a firm and profitably split it up and sell it in parts.

\section{Replacement Manager Divestiture}

When the circumstances are such that the divestiture premium is positive $\left(\mathrm{W}_{\mathrm{I}}>0\right)$ and the current managers do not undertake a divestiture, shareholders may also realize the true value of their investment by replacing incumbent managers with new managers who split up the firm and realize its maximum value. To the extent incumbent managers are not replaced may be an indication that the cost of replacing the incumbent managers is prohibitive (Shleifer \& Vishny, 1989). The cost incurred by current shareholders to replace incumbent managers with new managers who will initiate the divestiture is denoted by $g>0$. The cost of replacing incumbent managers is excessive when $\mathrm{g}>\mathrm{W}_{\mathrm{I}}$. In other words, it costs shareholders more to replace the managers than they gain from the divestiture.

If incumbent managers maximize the market value of the firm, shareholders receive $V_{t}$, with a net gain of $\mathrm{W}_{\mathrm{I}}$. However, if new managers must be hired to realize the maximum value of the firm, shareholders would receive a net gain of:

$\left(\mathrm{V}_{\mathrm{t}}-\mathrm{g}\right)-\mathrm{V}_{\mathrm{m}}=\left(\mathrm{V}_{\mathrm{t}}-\mathrm{V}_{\mathrm{m}}\right)-\mathrm{g}=\left(\mathrm{W}_{\mathrm{I}}-\mathrm{g}\right)<\mathrm{W}_{\mathrm{I}}$

The existing the shareholders' net gain is now reduced by the cost of replacing the incumbent managers. This indicates that incumbent manager divestitures are always more favorable to the shareholders than do replacement manager divestitures.

\section{Outside Manager Divestiture}

When incumbent managers do not undertake a divestiture, and shareholders fail to hire new managers, outsiders must take over the firm in order to realize its maximum value. In those circumstances, incumbent shareholders receive the existing market value plus the takeover premium paid by the outsiders. This is less than the amount current shareholders receive either when incumbent managers make the decision to divest or shareholders replace the incumbent managers with new managers who then undertake the divestiture. Recall that existing shareholders 
$\underline{1}$

receive the gain from divestiture, which is equal to $\left(\mathrm{V}_{\mathrm{t}}-\mathrm{V}_{\mathrm{m}}\right)$ when incumbent managers spit up the firm and equal to $\left(\mathrm{V}_{\mathrm{t}}-\mathrm{V}_{\mathrm{m}}\right)-\mathrm{g}$ when new managers are hired to undertake the divestiture. When incumbent managers do not undertake a divestiture, wealth-maximizing shareholders are faced with two choices; they either hire new managers or sell the firm to outsiders. Shareholders would not replace the incumbent managers when the costs are prohibitive, that is, when $\mathrm{g}>\mathrm{W}_{\mathrm{I}}$. Furthermore, even when the costs are not prohibitive, it may still be irrational to hire new managers to undertake the divestiture. Such is the case when the net gain from a divesture undertaken by the new managers is less than the takeover premium that could be obtained from outsiders $\left(\mathrm{W}_{\mathrm{I}}-\mathrm{g}<\mathrm{p}\right)$. Consequently, we should not observe situations where shareholders hire new managers and receive a net payout $\left(\mathrm{V}_{\mathrm{t}}-\mathrm{g}\right)$, which is less than the payment they could receive by selling the firm to outsiders for $\left(\mathrm{V}_{\mathrm{m}}+\mathrm{p}\right)$. Therefore, $\left(V_{t}-g\right)-\left(V_{m}+p\right)$ is always positive. condition:

The proceeds to existing shareholders under the three scenarios would therefore satisfy the following $\mathrm{V}_{\mathrm{t}}>\left(\mathrm{V}_{\mathrm{t}}-\mathrm{g}\right)>\left(\mathrm{V}_{\mathrm{m}}+\mathrm{p}\right)$

Subtracting the existing market value of the firm as a single entity from the payout to the existing shareholders in each case yields the net gain from divestiture under the three scenarios. The net gain received by existing shareholders is $V_{t}-V_{m}$ when incumbent managers undertake the divestiture. The net gain to existing shareholders when new managers are hired to divest is $V_{t}-g-V_{m}$ and $V_{m}+p-V_{m}$ when the firm is taken over by outsiders. Using the relationship in Equation 3 yields:

$\mathrm{V}_{\mathrm{t}}-\mathrm{V}_{\mathrm{m}}>\left(\mathrm{V}_{\mathrm{t}}-\mathrm{g}-\mathrm{V}_{\mathrm{m}}\right)>\left(\mathrm{V}_{\mathrm{m}}+\mathrm{p}-\mathrm{V}_{\mathrm{m}}\right)$, which implies that $\mathrm{W}_{\mathrm{I}}>\mathrm{W}_{\mathrm{I}}-\mathrm{g}>\mathrm{p}$.

This suggests that existing shareholders also fare better when they replace incumbent managers rather than wait for the point where it becomes economical for outsiders to acquire the firm.

The implication is that the full incremental value from splitting up the firm goes to the current shareholders if incumbent managers split up the firm. If new managers are hired to do the split-up, the shareholders' portion of the incremental value is reduced by the cost incurred by the shareholders to replace existing managers with new managers. If the firm is taken over the shareholders receive a net gain equal only to the takeover premium and the new owners of the firm keep the residual $(v)$. The outsiders' gain from the divestiture is equal to $v-c>0$, since they must at least cover the costs of gathering and processing information.

$\left(\mathrm{V}_{\mathrm{t}}-\mathrm{V}_{\mathrm{m}}-\mathrm{p}\right)=\mathrm{W}_{\mathrm{I}}-\mathrm{p}=\mathrm{v}>\mathrm{c}$

The profits that accrues to the outsiders who take over the firm, split it up and sell the parts, $\Pi_{\mathrm{O}}$ is equal to $v-\mathrm{c}$.

\section{CONCLUSION}

Like post-acquisition sell-offs, incumbent manager-initiated divestitures generate cash when these managers divest to realize the true value of firms. Both the acquisition and sell-off by outsiders and divestitures by incumbent managers achieve the same objective of maximizing the value of the firm when its value in parts is greater than that of the single entity. The difference in the outcome is that existing shareholders receive a greater benefit when the value-maximizing decision to split up the firm is initiated by incumbent managers, as opposed to new managers or outsider acquirers. 
Our theory suggests that it is always more profitable to existing shareholders to split up the firm when the value in parts exceeds the value of the firm as a single entity. The question therefore arises: Why do some firms require a takeover or management replacement to initiate a divestiture? We posit that there are frictions in the market or the governance structures of these firms that inhibit them from realizing their true value. Governance mechanisms such as ownership structure and ownership concentration are possible factors. Other characteristics of the firm such as CEO compensation, the structure of CEO compensation, as well as the firm's investment opportunities may cause incumbent management to resist divestiture to the point where replacement or takeover is necessary. Nixon, Rosenfeldt \& Sicherman (2000) analysis of 128 divestitures between 1988 and 1993 finds evidence that internal control mechanisms influence the choice of method incumbent managers use to do a divestiture. The potent theoretical argument we have presented is profuse with ideas that raise interesting empirical questions. An examination of the governance mechanisms we have identified and that have been associated with firm performance is a logical direction to advance this area of research.

\section{REFERENCES}

1. Bergh, Donald G., "Predicting divestitures of unrelated acquisitions: An integrative model of ex ante conditions," Strategic Management Journal 18(9), 715-731, 1997.

2. Kaplan, Steven N. \& Michael S. Weisbach, "The success of acquisitions: Evidence from divestitures," Journal of Finance 47(1), 107-138, 1992.

3. Mitchell, Mark \& Kenneth Lehn, "Do bad bidders become good targets?" Journal of Political Economy 98, 372-398, 1990.

4. Nixon, Terry D., Rodney L. Rosenfeldt, \& Seil W. Sicherman, "The choice between spin-offs and selloffs," Review of Quantitative Finance and Accounting 14(3), 277-288, 2000.

5. Porter, Michael E., "From competitive advantage to corporate strategy," Harvard Business Review, 65(3), 43-59, 1987.

6. Roll, Richard, "The hubris hypothesis of corporate takeovers," Journal of Business, 63, 197-216, 1986.

7. Shleifer, Andrei \& Robert Vishny, "Managerial Entrenchment: The case of firm-specific assets," Journal of Financial Economics 25, 123-139, 1989.

8. $\quad$ Steiner, Thomas L., "The corporate sell-off decision of diversified firms," Journal of Financial Research 20, 231-241, 1997. 
Notes 